\title{
Stock Price Behavior of Pure Capital Structure Issuance and Cancellation Announcements
}

\author{
Robert M. Hull*
}

\begin{abstract}
I examine planned senior-for-junior and junior-for-senior transactions that are subsequently cancelled. I find statistically significant stock returns for issuance and cancellation announcements that are positively related to the direction of the leverage change. The magnitude and direction of the returns differ from previous research. Discrepancies are attributed to different issuance purposes.
\end{abstract}

\section{Introduction}

Cancellation research (e.g., Officer and Smith (1986) and Mikkelson and Partch (1988)) examines the market response to issuance and cancellation announcements of senior and junior security offerings. These studies investigate offerings where the proceeds are primarily used to alter the asset structure.

In this cancellation study I investigate issuance and cancellation announcements for offerings that alter the capital structure. Such offerings are referred to as pure capital structure changes since the asset structure is not directly modified. I examine two types of pure capital structure changes: senior issues that reduce junior claims, and junior issues that reduce senior claims. I not only analyze observations that are fully cancelled and are listed on the New York Stock Exchange (NYSE) and the American Stock Exchange (AMEX), but I also investigate observations that are partially cancelled and are listed over-the-counter (OTC).

\section{Capital Structure Models}

The Modigliani and Miller (1963) tax model demonstrates that the presence of corporate taxes cause a positive relation between the direction of a pure leverage change and stock value. The debt level signaling model of Ross (1977) also hypothesizes a positive relation because increases (decreases) in debt levels signal positive (negative) managerial information about future cash flows. The Leland and Pyle (1977) signaling model offers a like prediction if the market anticipates that insider stockholdings are positively related to the direction of the leverage change.

\footnotetext{
* The author can be contacted through email at rob.hull@washburn.edu. The author would like to acknowledge that the paper has benefited from presentations at the Midwest Finance Association and Washburn School of Business. The author would also like to thank George Pinches and two anonymous referees for helpful comments.
} 
The Journal of Financial Research, Vol. XVII, No. 3, Fall 1994, pp. 439-448, Robert M Hull

Agency models, such as Jensen and Meckling (1976), have predictions similar to Leland and Pyle (1977) since insiders can include managers.

Signaling models (e.g., Myers and Majluf (1984) and Miller and Rock (1985)) do not generally apply when analyzing pure leverage changes. These models hypothesize that a security offering that alters the asset structure conveys unfavorable information to the market. Thus, these models assert a negative (positive) relation between the direction of the leverage change and stock value for debt (equity) offerings.

\section{Prior Pure Capital Structure Change Findings}

Event studies of security offerings can be classified as "noncash" and "cash". Noncash offering studies examine pure leverage changes consisting of exchange offers and private swaps. These studies support Modigliani and Miller (1963), Ross (1977), Leland and Pyle (1977), and Jensen and Meckling (1976). The exchange offer study of Masulis (1980) supports Modigliani and Miller (1963). The private swap study of Israel, Ofer and Siegel (1989) offers evidence for Ross (1977). The combined exchange offer and private swap study of Cornett and Travlos (1989) mentions support for Leland and Pyle (1977) and Jensen and Meckling (1976).

Cash offering studies involve security offerings where the cash proceeds are used to alter the asset structure, capital structure, or both. Cash offering studies that include observations that alter the capital structure are confined to junior offerings that reduce debt. These studies find that stock price behavior is consistent with signaling and agency models. Masulis and Korwar (1986) offer evidence consistent with Leland and Pyle (1977), Jensen and Meckling (1976), and Miller and Rock (1985). Mikkelson and Partch (1986) cite support for Myers and Majluf (1984). Mikkelson and Partch (1988) note general support for models that argue that equity issues are viewed by investors as negative signals.

Modigliani and Miller (1963) and Ross (1977) are less frequently cited by cash offering studies. This is because the samples they analyze consist of junior offerings where the purpose is less likely to involve debt reduction.

\section{Prior Cancellation Findings}

Table 1 reports findings for the six prior cancellation studies. Except for Masulis (1980), who does not report two-day cumulative excess returns (CERs), the studies do not focus upon pure leverage changes. Furthermore, the studies do not typically analyze cancellation samples based upon issuance purposes. An exception is Mikkelson and Partch (1988), who analyze withdrawn equity offerings $(n=62)$, and find similar issuance and cancellation CERs between those that refinance debt $(n=25)$ and those that finance capital expenditures $(n=14)$.

Table 1 displays the conflicting findings given by the four senior offering studies. Masulis (1980) reports a significant negative three-day CER of -6.86 percent. He writes that the two- day issuance CER is of a similar 
The Journal of Financial Research, Vol. XVII, No. 3, Fall 1994, pp. 439-448, Robert M Hull

magnitude but opposite sign. Jensen and Pugh (1991) find significant negative issuance and cancellation CERs compatible with Miller and Rock (1985). Officer and Smith (1986) find a significant negative issuance CER and an insignificant negative cancellation CER consistent with the Myers and Majluf (1984) and Leland and Pyle (1977). Mikkelson and Partch (1988) find neutral issuance and cancellation CERs (inconsistent with signaling models.

Table 1 reveals similar findings among the four junior studies. Each discovers a significant negative issuance CER that is greater in absolute magnitude than the corresponding significant positive cancellation CER. These studies note support for Leland and Pyle (1977), Myers and Majluf (1984), Jensen and Meckling (1976).

\section{Data}

The primary sources of this study's security offering announcements are The Wall Street Journal and the Investment Dealers' Digest. Sources for the summary statistics and data needed for statistical tests are: the above two sources, Compustat Annual Files, Moody's Industrial Manuals, Center for Research of Security Prices (CRSP) OTC Price and Return Files, and CRSP NYSE/AMEX Price and Return Files. The sources cover the years from 1970 through 1989.

The sample consists of 30 senior offerings and 156 junior offerings with identifiable issuance announcement dates that (survive the following four screens:

1. Each must be identified as a pure capital structure change.

2. Each must be partially or fully cancelled.

3. Each must not be identified as a utility.

4. Each must be listed on the CRSP OTC Return File or CRSP NYSE/AMEX Return File and have sufficient trading data to calculate its two-day CER.

Most of the senior offerings ( $\mathrm{n}=9$ ) occur during 1974 (in contrast to 5 junior offerings), while most of the junior offerings ( $\mathrm{n}=28$ ) occur during 1983 (in contrast to zero senior offerings). The 30 senior offerings include 3 OTC observations, 7 partially cancelled observations, 27 exchange offers, and 26 equity-for-nonconvertible debt transactions. Of the 156 junior offerings, there are 43 OTC observations, 88 partially cancelled observations, 9 exchange offers, 33 private swaps, and 138 equity-for-nonconvertible debt transactions. Only one-fifth of the junior announcements specify that the retired debt is short- term. In general, there is no evidence that the short-term debt was recently acquired to finance capital expenditures.

Table 2 reports summary statistics for the senior and junior security offering samples. The senior sample (relative to the junior sample) consists of smaller firms that undergo relatively greater changes in leverage. As expected, partially cancelled observations involve relatively smaller changes in leverage than do fully cancelled observations. 
The Journal of Financial Research, Vol. XVII, No. 3, Fall 1994, pp. 439-448, Robert M Hull

\section{Methodology}

The ordinary least squares (OLS) procedure described by Brown and Warner (1985) is used to test the hypothesis that a sample's two-day CER is equal to zero. A two-day CER consists of the announcement date (day 0 ) and the day after $($ day +1$)$. Day +1 is included because the market may be closed when the offering is revealed on the announcement date.

To overcome problems resulting from nonsynchronous trading data, the standard OLS alphas and betas are replaced with those obtained by using the Scholes and Williams (1977) procedure. Alphas and betas are calculated using a post-estimation period that begins 40 trading days after the announcement and ends 200 days later. The equally weighted CRSP OTC and CRSP NYSE/AMEX indices are used for OTC and NYSE/AMEX firms. Similar (but unreported) announcement period results are found when employing the standard OLS alphas and betas; other comparison periods; the value weighted index; and, other event period models.

Table 3 presents two-day CER results for issuance and cancellation announcements. CERs are reported for the previously described sample (which is now referred to as the "unclean" sample) and a "clean" sample. The clean sample is formed from the unclean sample by deleting observations that have (i) a firm- specific announcement for event days -3 to +3 around either its issuance or cancellation announcement date or (ii) an issuance (cancellation) announcement date with no corresponding identifiable cancellation (announcement) date.

Table 3 reports similar CERs for the unclean and clean samples. CERs are statistically significant and positively related to the direction of the leverage change for all fully cancelled portfolio tests. These results offer support for Modigliani and Miller (1963) and Ross (1977). Leland and Pyle (1977) and Jensen and Meckling (1976) are also supported if changes in insider ownership proportions are positively related to the direction of the leverage change.

The signs for the cancellation CERs for the total samples of senior and junior offerings mirror the CERs found for the fully cancelled portfolios. Although the number of senior partial cancellations is much too small to generate definitive conclusions, the price change behavior for these observations parallels that for the junior partial cancellations. For example, the sign of the partially cancelled two-day CER resembles the sign of the issuance two-day CER. It appears as if the market reacts more to the reaffirmation of the issuance announcement (that in some cases may even be in doubt) than to the partial cancellation.

\section{Senior-for-Junior Fully Cancelled Results}

Table 3 reports a greater positive issuance CER and a less negative cancellation CER than suggested by Masulis (1980). No evidence can be offered that late reporting, leakage, or outliers explain discrepancies. Differences may reflect dissimilar time periods since the Masulis study covers a time period that shows less resemblance to this study (relative to the other studies reported in Table 1). A smaller cancellation CER magnitude 
The Journal of Financial Research, Vol. XVII, No. 3, Fall 1994, pp. 439-448, Robert M Hull

(relative to the issuance CER magnitude) can be explained if the junior holders fear the premium being offered is not adequate. A cancellation based upon refusal by current owners would convey a belief that the stock is undervalued. This scenario is possible since (when reported) the financial press states the cancellation is caused by lack of cooperation from current owners.

The two-day CER results for the senior-for-junior fully cancelled portfolio contrast sharply with the senior offering studies of Officer and Smith (1986), Mikkelson and Partch (1988), and Jensen and Pugh (1991). The differences in signs and magnitudes suggest that the purpose of the senior issue determines the market's issuance and cancellation responses.

To illustrate, Leland and Pyle (1977) and Jensen and Meckling (1976) predict that senior issuance announcements that retire stock signal positive news if the market believes insiders are not relinquishing stockholdings. To the extent the cancellation is initiated by insiders, the positive signalling effect is reversed. Furthermore, senior issuance announcements that reduce junior securities are essentially free of the negative signaling effects predicted by Myers and Majluf (1984) and Miller and Rock (1985).

\section{Junior-for-Senior Fully Cancelled Results}

Table 3 reveals that the two-day CER signs for junior-for- senior announcements for the fully cancelled portfolio are the same as reported in Table 1 . However, the CER magnitudes differ. This is especially evident for the clean sample where the magnitudes of -2.52 percent and 3.39 percent for the issuance and cancellation CERs contrast with the corresponding weighted average magnitudes of -3.47 percent and 1.83 percent reported in Table 1. No evidence can be offered that late reporting, leakage, or outliers account for differences. Also, deleting the 9 noncash and 19 OTC offerings do not explain the discrepancy.

The most plausible explanation for the magnitude discrepancy appears to be the purpose of the issue. Negative signaling effects, associated with Myers and Majluf (1984) and Miller and Rock (1985), are not hypothesized to impact issuance CERs for pure leverage changes. This can explain why pure leverage decreases have smaller negative magnitudes. These effects would have to be especially strong for prior junior offering studies since the negative effects predicted by Modigliani and Miller (1963) and Ross (1977) is expected to be weaker if nondebt reduction is the dominant purpose.

The more positive cancellation CER for this study's pure leverage decrease sample is consistent with Modigliani and Miller (1963) and Ross (1977). The positive cancellation effects would be less likely for junior offerings that include both debt and nondebt reduction purposes.

I examine planned senior-for-junior and junior-for-senior transactions that are subsequently cancelled. I find statistically significant issuance and cancellation CERs that are positively related to the direction of the leverage change. The magnitude and direction of these CERs differ from prior cancellation studies that do not focus on pure leverage changes. 
The Journal of Financial Research, Vol. XVII, No. 3, Fall 1994, pp. 439-448, Robert M Hull

Dissimilarities in CERs can be attributed to differences in issuance purposes. Issuance announcements for pure leverage changes are not accompanied by negative signaling effects hypothesized by Myers and Majluf (1984) and Miller and Rock (1985) for offerings that change the asset structure. Also, pure leverage increases are dominated by exchange offers where the market likely perceives that insiders are trying to increase ownership proportions. As predicted by Leland and Pyle (1977) and Jensen and Meckling (1976), this would cause pure leverage increases to experience positive issuance and negative cancellation CERs. Finally, Modigliani and Miller (1963) and Ross (1977) predict a positive cancellation CER for pure leverage decreases.

Analysis of partially cancelled junior and senior portfolios finds that partially cancelled announcements are not positively related to the direction of the leverage change. This suggests that such announcements are unable to reverse the valuation effect that accompanies the issuance announcement. Finally, the inclusion of OTC and private swap observations do not account for the differences between this study and prior cancellation studies.

\section{FOOTNOTES:}

Mikkelson and Partch (1986) and Masulis and Korwar (1986) analyze noncancellation samples based upon issuance purposes, but reach no general agreement between that purpose of the offering and the change in stock value.

Officer and Smith (1986) find that the cancellations of their debt issues are anticipated due to adverse firm-specific information. They argue that the ability of the market to anticipate bond withdrawal announcements prevents a significant negative two-day CER.

The actual number of cancellation observations can differ slightly from those given for the issuance announcements because (i) an issuance (cancellation) announcement can have a corresponding cancellation (issuance) date that is unknown, or (ii) an issuance announcement can have two partial cancellation announcements (or a cancellation announcement can cancel two separate issuance announcements). There are 27 leverage increase cancellation announcements and 162 leverage decrease cancellation announcements.

Day 0 and day +1 are the only event days from -15 to +15 that are statistically significant. 
Table 1

\begin{tabular}{|c|c|c|c|c|c|c|c|}
\hline \multirow[b]{2}{*}{ Study } & \multirow[b]{2}{*}{ Years } & \multicolumn{3}{|c|}{ Senior Offerings: } & \multicolumn{3}{|c|}{ Junior Offerings: } \\
\hline & & $\mathrm{N}$ & Issue & Cancel & $\mathrm{N}$ & Issue & Cancel \\
\hline Masulis (1980) & $1963-76$ & 20 & NR & NR & & & \\
\hline $\begin{array}{l}\text { Jensen and } \\
\text { Pugh (1991) }\end{array}$ & $1974-87$ & 44 & $-0.93 \%$ & $-0.87 \%$ & & & \\
\hline $\begin{array}{l}\text { Officer and } \\
\text { Smith (1986) }\end{array}$ & $1974-84$ & 30 & $-2.66 \%$ & $-0.34 \%$ & 31 & $-4.66 \%$ & $2.54 \%$ \\
\hline $\begin{array}{l}\text { Mikkelson and } \\
\text { Partch (1988) }\end{array}$ & $1974-83$ & 21 & NR & NR & 62 & $-2.99 \%$ & $1.24 \%$ \\
\hline $\begin{array}{l}\text { Mikkelson and } \\
\text { Partch (1986) }\end{array}$ & $1972-82$ & & & & 14 & $-5.72 \%$ & $4.13 \%$ \\
\hline $\begin{array}{l}\text { Masulis and } \\
\text { Korwar (1986) }\end{array}$ & $1963-80$ & & & & 27 & $-2.03 \%$ & $1.20 \%$ \\
\hline $\begin{array}{l}\text { Weighted Average } \\
\text { For Reported CER }\end{array}$ & & 37 & $-1.63 \%$ & $-0.66 \%$ & 34 & $-3.47 \%$ & $1.83 \%$ \\
\hline
\end{tabular}

NR indicates that the two-day CER is not reported.

All 20 senior issues are exchanged for junior issues. A three-day CER for cancellation announcements of -6.86 percent is noted.

The two-day CER for the issuance announcements is reported to be about the same magnitude but positive.

Reported purposes do not include reducing junior securities.

Although not formally stated, it is assumed that the proceeds are primarily used to alter the asset structure.

Indicates that the CER is not statistically significant.

Reported purposes include both debt and nondebt reduction.

All weighted average values reflect two-day CERs for samples where pure leverage changes are either in the minority or not found. Less than one in five junior offerings is expected to reduce debt according to collective data suggested by Mikkelson and Partch $(1986,1988)$ and Masulis and Korwar (1986). 


\begin{tabular}{lrrrr}
\hline TABLE 2 & $\begin{array}{r}\text { Senior Issues } \\
\text { Mean (Median) }\end{array}$ & $\begin{array}{r}\text { Junior Issues } \\
\text { Mean (Median) }\end{array}$ \\
Variable & $\$ 171 \mathrm{M}$ & $(\$ 27 \mathrm{M})$ & $\$ 1,002 \mathrm{M}$ & $(\$ 190 \mathrm{M})$ \\
\hline Firm Value & $\$ 87 \mathrm{M}$ & $(\$ 14 \mathrm{M})$ & $\$ 607 \mathrm{M}$ & $(\$ 69 \mathrm{M})$ \\
Market Value of Common Stock & $\$ 32 \mathrm{M}$ & $(\$ 7 \mathrm{M})$ & $\$ 34 \mathrm{M}$ & $(\$ 17 \mathrm{M})$ \\
New Offering Value & $-21 \%$ & $(-16 \%)$ & $19 \%$ & $(12 \%)$ \\
$\begin{array}{l}\text { Percentage Change in Common } \\
\quad \text { Stock }\end{array}$ & $31 \%$ & $(23 \%)$ & $15 \%$ & $(12 \%)$ \\
$\begin{array}{l}\text { Fully Cancelled Issue Value } \\
\quad \text { Divided by Firm Value }\end{array}$ & & & & \\
$\begin{array}{l}\text { Partially Cancelled Issue Value } \\
\quad \text { Divided by Firm Value }\end{array}$ & $15 \%$ & $(10 \%)$ & $4 \%$ & $(2 \%)$ \\
\hline
\end{tabular}

The 30 senior-for-junior transactions include 24 nonconvertible debt-for-common, 2 nonconvertible debt-forconvertible preferred, 2 nonconvertible debt-for-convertible debt, 1 convertible debt-for-common, and 1 nonconvertible preferred-for-convertible preferred.

The 156 junior-for-senior transactions include 127 common-for-nonconvertible debt, 11 convertible preferred-fornonconvertible debt, 1 nonconvertible preferred-for-nonconvertible debt, 9 convertible debt-for-nonconvertible debt, 5 common-for-convertible debt, 1 common-for-income bond, 1 common-for-nonconvertible preferred, and 1 common-for-convertible preferred.

The market value of the common stock plus book value of long-term debt and short-term debt (notes payable and debt due within one year) plus the liquidation value of preferred stock as given by sources that occur closest, yet prior, to event day -1 .

Price prior to the announcement date times outstanding shares as given by sources that occur closest, yet prior, to that date.

Based upon values by sources on the initial announcement date.

For those observations that do not involve a net change in common stock the percentage change in common stock is zero.

The leverage increase sample has 23 (7) observations that are fully (partially) cancelled, while the leverage decrease sample has 68 (88) observations that are fully (partially) cancelled. 


\begin{tabular}{|c|c|c|c|}
\hline TABLE 3 & $\begin{array}{l}\text { Total } \\
\text { Sample }\end{array}$ & $\begin{array}{c}\text { Fully } \\
\text { Cancelled } \\
\text { Portfolio }\end{array}$ & $\begin{array}{l}\text { Partially } \\
\text { Cancelled } \\
\text { Portfolio }\end{array}$ \\
\hline Unclean: & $(n=30)$ & $(n=23)$ & $(n=7)$ \\
\hline Issuance Results: & $\begin{array}{c}10.95 \%: 83 \% \\
4.83^{*}\end{array}$ & $\begin{array}{c}11.59 \%: 87 \% \\
4.20^{*}\end{array}$ & $\begin{array}{l}8.83 \%: 71 \% \\
2.37^{*}\end{array}$ \\
\hline Cancellation Results: & $\begin{array}{l}-2.66 \%: 37 \% \\
-1.60\end{array}$ & $\begin{array}{l}-4.74 \%: 35 \% \\
-2.62^{* *}\end{array}$ & $\begin{array}{c}3.27 \%: 43 \% \\
1.10\end{array}$ \\
\hline Clean & $(n=20)$ & $(n=14)$ & $(n=6)$ \\
\hline Issuance Results: & $\begin{array}{c}11.89 \%: 85 \% \\
4.00^{*}\end{array}$ & $\begin{array}{c}13.02 \%: 93 \% \\
3.37^{*}\end{array}$ & $\begin{array}{c}9.26 \%: 67 \% \\
2.11^{* * *}\end{array}$ \\
\hline \multirow[t]{2}{*}{ Cancellation Results: } & $\begin{array}{l}-2.56 \%: 30 \% \\
-1.63\end{array}$ & $\begin{array}{l}-4.11 \%: 29 \% \\
-2.15^{* *}\end{array}$ & $\begin{array}{l}1.05 \%: 33 \% \\
0.95\end{array}$ \\
\hline & $\begin{array}{l}\text { Total } \\
\text { Sample }\end{array}$ & $\begin{array}{l}\text { Fully } \\
\text { Cancelled } \\
\text { Portfolio }\end{array}$ & $\begin{array}{l}\text { Partially } \\
\text { Cancelled } \\
\text { Portfolio }\end{array}$ \\
\hline Unclean: & $(n=156)$ & $(n=68)$ & $(n=88)$ \\
\hline Issuance Results: & $\begin{array}{c}-2.51 \%: 32 \% \\
-6.64^{\star}\end{array}$ & $\begin{array}{c}-2.86 \%: 35 \% \\
-4.41^{*}\end{array}$ & $\begin{array}{c}-2.34 \%: 28 \% \backslash \\
-4.97^{\star}\end{array}$ \\
\hline Cancellation Results: & $\begin{array}{c}0.73 \%: 49 \% \\
1.87^{* * *}\end{array}$ & $\begin{array}{l}2.94 \%: 71 \% \\
4.30^{*}\end{array}$ & $\begin{array}{l}-1.08 \%: 31 \% \\
-3.29^{*}\end{array}$ \\
\hline Clean: & $(n=120)$ & $(n=54)$ & $(n=66)$ \\
\hline Issuance Results: & $\begin{array}{l}-2.41 \%: 32 \% \\
-5.63^{*}\end{array}$ & $\begin{array}{l}-2.52 \%: 31 \% \\
-4.07^{*}\end{array}$ & $\begin{array}{l}-2.32 \%: 27 \% \\
-3.89^{*}\end{array}$ \\
\hline Cancellation Results: & $\begin{array}{l}1.18 \%: 53 \% \\
2.55^{*}\end{array}$ & $\begin{array}{l}3.93 \%: 80 \% \\
5.17^{\star}\end{array}$ & $\begin{array}{l}-1.07 \%: 30 \% \\
-3.10^{*}\end{array}$ \\
\hline
\end{tabular}

Notes:

The first row gives the portfolio two-day cumulative excess return followed by the percent of positive observations. The second row gives the t-statistic (when testing the hypothesis that the portfolio two-day cumulative excess return equals zero) followed by the level of significance as given below:

* Significant at the 0.01 level.

** Significant at the 0.05 level.

*** Significant at the 0.10 level. 


\section{REFERENCES}

Brown, S. and J. Warner, 1985. Using daily stock returns: The case of event studies, Journal of Financial Economics 14 (March), 3-31

Cornett, M. and N. Travlos, 1989, Information effects associated with debt-for-equity and equity-for-debt exchange offers, Journal of Finance 44 (June), 451-468.

Israel, R., A. Ofer, and D. Siegel, 1989, The information content of equity-for-debt swaps, Journal of Financial 25 (December), 249-370.

Jensen, Michael, and W. Meckling, 1976, Theory of the firm: Managerial behavior, agency costs and ownership structure, Journal of Financial Economics 3 (October), 305-360.

Jensen, Marlin, and W. Pugh, 1991, Valuation effects of cancelled debt offerings, Journal of Financial and Quantitative Analysis 26 (September), 425-431.

Leland, H. and D. Pyle, 1977, Informational asymmetries, financial structure, and financial intermediation, Journal of Finance 32 (May), 371-388.

Masulis, R., 1980, The effects of capital structure change on security prices: A study of exchange offers, Journal of Financial Economics, 8(2),139-178.

Masulis, R. and A. Korwar, 1986, Seasoned equity offerings: An empirical investigation, Journal of Financial Economics 15 (January/February), 91-118

Mikkelson, W. and M. Partch, 1986, Valuation effects of security offerings and the issuance process, Journal of Financial Economics 15 (January/February), 31-60.

Mikkelson, W. and M. Partch, 1988, Withdrawn security offerings, Journal of Financial and Quantitative Analysis 23 (June), 119-133.

Miller, M. and K. Rock, 1985, Dividend policy under asymmetric information, Journal of Finance 40 (December), 1031-1050.

Modigliani, F. and M. Miller, 1963, Corporate income taxes and the cost of capital: A correction, $53,433-443$.

Myers, S. and N. Majluf, 1984, Corporate financing and investment decisions when firms have information that investors do not have, Journal of Financial Economics 13 (June), 187-221.

Officer, D. and R. Smith, II., 1986, Announcement effects of withdrawn security offerings: Evidence on the wealth redistribution hypothesis, Journal of Financial Research 9, 229-238.

Ross, S., 1977, The determination of financial structure: The incentive-signaling approach Bell Journal of Economics 8 (Spring), 23-40.

Scholes, M. and J. Williams, 1977, Estimating betas from nonsynchronous data, Journal of Financial Economics 5 (December), 309-328. 